\title{
GENDER-BASED DIFFERENCES IN INTERNET USE AMONG GRAMMAR SCHOOL STUDENTS IN THE CZECH REPUBLIC
}

Jaromír BASLER*, Univerzita Palackého v Olomouci, Česká republika Michal MRÁZEK, Univerzita Palackého v Olomouci, Česká republika

Přijato: 5. 8. 2019 / Akceptováno: 4. 12. 2019

Typ článku: Teoretická studie

DOI: $10.5507 /$ jtie.2019.011

Abstract: The present paper describes the partial results of a research study focusing on an analysis of gender-based differences in internet use among students in grade three in grammar schools in Olomouc region, Pardubice region, Moravian-Silesian region, and Zlín region in the Czech Republic. In terms of methodology, the research strategy was of a quantitative design. The research method to obtain data was a questionnaire with a mixed typology of questionnaire items. The study comprised 529 respondents, who received a printed version of the questionnaire in cooperation with the schools involved in the study. The data were recorded electronically; for this reason the printed questionnaires were converted into a digital format. The electronic data were processed and analysed using a spreadsheet application and specialized statistical software. The evaluation of the research data was based on the hypotheses, which were tested using an analysis of basic as well as advanced data processing.

Keywords: internet use, internet addiction, online computer games, social networks, grammar school student, quantitative research, questionnaire.

\section{GENDEROVÉ ROZDÍLY VE VYUŽÍVÁNÍ INTERNETU MEZI ŽÁKY GYMNÁZIÍ V ČESKÉ REPUBLICE}

Abstrakt: Předkládaný článek popisuje dílči výsledky výzkumu, který se zaměřje na analýzu genderových rozdilì využívání internetu u žáků 3. ročníki̊ gymnázii v regionech krajů Olomouckého, Pardubického, Moravskoslezského a Zlínského $v$ České republice. Design výzkumné strategie byl metodologicky zvolen formou kvantitativně orientovaného výzkumu. Jako výzkumná metoda získávání dat byl stanoven dotazník, ve kterém byla použita smíšená typologie dotazníkových položek. Celkový počet zúčastněných respondentũ činil 529, kterým byl dotazník distribuován $v$ tištěné podobě ve spolupráci s jednotlivými školami. Evidence ziskaných dat probihala elektronicky, $k d y$ bylo nutné všechny tištěné dotazniky převést do digitální podoby. Data v elektronické podobě byly zpracovány a analyzovány v tabulkovém procesoru a ve specializovaném softwaru pro statistické výpočty. Př́ vyhodnocováni výzkumných dat bylo nutné vycházet z podoby stanovených hypotéz, jež byly ověrovány z výsledků analýzy základního i pokročilého zpracování dat.

Klíčová slova: využívání internetu, závislost na internetu, on-line počítačové hry, sociální sítě, žák gymnázia, kvantitativní výzkum, dotazník.

*Autor pro korespondenci: jaromir.basler@upol.cz 


\section{1 Úvod a vymezení problematiky}

Internet se stal globálním fenoménem a již se jedná o základní součást lidského života všech věkových skupin. Nadměrné využívání internetu ovšem může mít velký počet negativních důsledků a mohou se objevit až závislostní projevy. Závislost na internetu může mít nepříznivé účinky na psychosociální vývoj adolescentů, dochází k pohlcení většiny volného času, k úzkostnému a často nekontrolovatelnému chování (Tahiroglu et al., 2008). Může docházet také k pracovním, finančním i sociálním problémům. Mezi časté příznaky závislosti na internetu můžeme zařadit: nedostatek spánku, únava, nadměrné množství stráveného času na internetu, špatná pracovní výkonnost, apatie, podrážděnost a snížený zájem o společenské vztahy (Tonini et al., 2012). Závislostní užívání internetu můžeme dělit na tři skupiny: elektronická komunikace (sociální sítě, e-mail, chat aj.), nadměrné hraní on-line počítačových her, sexuální zaujetí (sledování a shromažd'ování společensky nevhodného obsahu aj.). Všechny tři typy mohou mít znaky závislostního chování jako např. abstinenční prríznaky, tolerance. Na začátku jsou nevýhody skryté a problematické chování dává uživateli jen potěšení, postupem času se však negativní působení akumuluje (Weinstein, Lejoyeux; 2010).

Závislost na virtuálních drogách (tedy i internetu) v jakékoliv formě se často označuje jako tzv. netolismus (Kopecký et al., 2015). Vacek (2010) uvádí, že odborníci se shodli na skutečnosti, že v podstatě každá závislost se skládá ze šesti základních symptomů (symptomy jsou definovány ve vztahu se závislostí konkrétně na internetu). Prvním symptomem je význačnost, kdy se služby internetu stávají velmi významným bodem života jedince. Internet začíná postupně ovlivňovat jeho myšlení (přemýšlení o využívání internetu, když zrovna vykonáváme jinou aktivitu), cítění (touha být na internetu) a chování (zanedbávání povinností). Dalším symptomem jsou změny nálady. Při uspokojování touhy se jedinci změní nálada (většinou pozitivně). S postupem závislosti se zvyšuje stále více tolerance $\mathrm{k}$ internetu, $\mathrm{z}$ toho důvodu jedinec potřebuje strávit stále více a více času uspokojováním touhy. Odvykací příznaky se vyskytují u každé závislosti, kdy se po ukončení uspokojující činnosti objeví neklid, stres, nervozita či vztek. Předposledním symptomem je konflikt (Klinika adiktologie, 2010), který může být dvojího druhu. Mezilidský konflikt vede k zanedbávání povinností a blízkých osob (hádky s rodiči, ztráta přátel aj.). Vnitřní konflikt vede k rozpolcenosti jedince, který se těžko rozhoduje mezi uživáním internetu a jinými aktivitami (nemůže se rozhodnout, zda má využívat služeb internetu nebo se věnovat př́pravě do školy či partnerovi). Posledním symptomem je relaps, kdy závislý má tendence opakovat své dřívější závislostní chování, se kterým nesouhlasí. Vrací se k nadměrnému využívání internetu po určité klidové fázi. Jedinec je závislý, pokud se u něj vyskytují všechny zmiňované symptomy. Z výčtu symptomů je zřejmé, že závislost má negativní dopad na život jedince (Basler, Mrázek, 2018). Užívání sítě Internet bylo zkoumáno v 11 evropských zemích na reprezentativním vzorku 11956 adolescentů (Sinkkonen et al., 2014) a prevalence patologického užívání internetu (těžká závislost) byla 4,4\% a prevalence maladaptivního užívání (mírná závislost) 14,3%. Většina patologických uživatelů byli muži. Muži trávili více času na internetu i hraním počítačových her, zatímco ženy používaly internet v nižší míře, spíše pro komunikaci (sociální sítě, e-mail aj.). V dalším výzkumu Sinkkonen et al. (2014), kterého se účastnilo celkem 475 studentů (15-19 let, 57 \% žen; $43 \%$ mužů), bylo pouze 1,3 \% studentů hodnoceno jako uživatelé s těžkou závislostí, hodnota uživatelů mírně závislých na internetu činila 22,9 \%. Jako důvod uživání internetu uvedlo 22,7 \% respondentů hledání 
informací; pro 19 \% respondentů internet sloužil jako nástroj pro zábavu; ovšem pouze 3,4 \% respondentů internet užívalo pro hraní počítačových her (Basler, Mrázek, 2018).

V rámci využívání tohoto fenoménu se spolu s hraním počítačových her vyskytuje mnoho genderových předsudkủ a výzkumných tvrzení např. muži využívají moderních informačních technologií více než ženy. Dalším tvrzením může být, že pokud ženy využívají tyto technologie, využívají je spíše pro vzdělávací účely na rozdíl od mužio, kteř́i je využívají především pro zábavu. Genderové rozdíly potvrzuji různé odborné zdroje např. Basler, Mrázek (2018); Suchá et al. (2018); Český statistický úřad (2017); ESA (2017), Thanuskodi (2013), Bakken et al. (2009), Green, McNeese (2008). Cílem příspěvku je předložit výzkumná zjištění zaměřující se na rozdíly ve využívání internetu mezi muži a ženami a také na rozdíly ve skóre závislosti na internetu mezi pohlavím. Předkládaný článek se tedy primárně zaměřuje na genderové rozdíly u našeho výzkumného vzorku. Realizace výzkumného šetření vychází z dlouhodobého řešení problematiky autory, kteří se především zaměřují na oblast využívání počítačových her u adolescentů. Do této oblasti spadá taktéž hraní on-line počítačových her a s tím spojené využívání internetu a možná rizika závislosti na internetu. Realizovaná analýza genderových rozdílů v souvislosti se závislostí na internetu navazuje na výzkumy světové úrovně a poskytuje reálný pohled na aktuální stav v cílovém regionu.

\section{Metodologie}

Jako výzkumná metoda byl zvolen standardizovaný Chenův dotazník (Chen et al., 2003; Ko et al., 2005; překlad dr. Vondráčková / Klinika adiktologie - Pavlovská, 2012) doplněný o několik upřesňujících doplňujících položek. Celkově dotazník obsahoval 31 položek - 26 položek vycházejících ze standardizovaných kritérií závislosti na internetu (4bodová sebehodnotící škála) a 5 nestandardizovaných položek doplňujících standardizovanou část (časové užívání internetu, jeho konkrétních služeb a pohlaví). Školy i respondenti byli před vyplněním dotazníku seznámeni, že veškerá získaná data budou anonymní. Dotazníkové šetření bylo provedeno u 3 . ročníků náhodně vybraných gymnázií České republiky v Olomouckém, Zlínském, Moravskoslezském, Jihomoravském a Pardubickém kraji. Do výzkumného šetření byly zapojeny školy pouze z městských aglomerací, nebot' se gymnázia na vesnicích v České republice běžně nevyskytují. Dotazníkového šetření se zúčastnilo celkem 10 gymnázií. Celkový vzorek respondentů výzkumného šetření, která probíhala v období od dubna do června 2018, činil 529 žáků 3. ročníků gymnázií. Dotazníky byly vyplňovány v hodinách za kontroly pedagogických pracovníků, kteří byli po dohodě předem instruováni, jak s dotazníkem pracovat. Tato skutečnost zajistila, že návratnost dotazníků byla $100 \%$. Administrace, základní zpracování a analýza veškerých získaných dat byly provedeny pomocí implementovaných funkcí programu Microsoft Excel. Na základě tohoto zpracování bylo možné data připravit do podoby, ve které mohly být importovány do statistického programu Statistica 13. Pomocí tohoto programu bylo možné dokazovat stanovené hypotézy s využitím statistického testu významnosti Studentův t-test.

\section{Výsledky}

Na základě studia odborných publikací např. Suchá et al. (2019); Basler, Mrázek (2018); Hellstrom et al. (2015); Chráska (2016); Lenhart et al. (2008); Longstreet et al. (2019); Messias et al. (2011); Müller et al. (2014); Ndasauka et al. (2019); Peeters et al. (2018); Tahiroglu et al. (2008); Tonini et al. (2012); Weinstein, Lejoyeux (2010) a na základě vlastních úvah byly stanoveny hypotézy $\mathrm{H}_{1}-\mathrm{H}_{5}$, jenž jsou vyhodnocené 
v následujícím textu př́spěvku. V rámci vyhodnocení každé hypotézy jsou uvedeny tabulky a krabicové grafy, jenž se vztahují ke zvolené statistické metodě. Dále jsou uvedeny taktéž histogramy četností a v př́padě potvrzení hypotézy jsou uvedeny histogramy četností zvlášt' pro každé pohlaví pro detailní popis výsledků.

\section{H1: Čas strávený využíváním internetu je u žáků 3. ročníků gymnázií delší u mužů než u žen.}

Cílem hypotézy bylo zjistit, zda jsou rozdíly v času využíváni internetu u mužů a žen (2 kategorie: muži, ženy). Hypotézu jsme dokazovali na základě odpovědí žákủ na otázku „O: Kolik hodin a minut v prüměru za jeden den trávite využíváním internetu?“ a „O: Pohlaví“. Pro vyhodnocení hypotézy byla použita statistická metoda Studentův t-test (Chráska, 2016). Pro potřeby statistického vyhodnocení výzkumné hypotézy byla stanovena nulová a alternativní hypotéza $\mathrm{H}_{0}$ a $\mathrm{H}_{\mathrm{A}}$ :

Ho: Čas strávený využíváním internetu je u žáků 3. ročníků gymnázií stejný u mužů a žen. $\mathbf{H A}_{\mathrm{A}}$ : Čas strávený využíváním internetu je u žáků 3. ročníkủ gymnázií delší u mužů než u žen.

\begin{tabular}{|c|c|}
\hline \multicolumn{2}{|c|}{\begin{tabular}{|l|} 
t-testy; grupováno: Pohlaví (DATA výzkum) \\
Skup. 1: Muž \\
Skup. 2: Žena \\
\end{tabular}} \\
\hline \multicolumn{2}{|c|}{ Proměnná } \\
\hline \multicolumn{2}{|c|}{ Využívání internetu (průměrná hodnota v min. za den) } \\
\hline Průměr Muž & 190,7423 \\
\hline Průměr Žena & 180,8840 \\
\hline $\mathrm{t}$ & 0,643981 \\
\hline SV & 485 \\
\hline $\mathrm{p}$ & 0,519892 \\
\hline Poč. plat. Muž & 194 \\
\hline Poč. plat. Žena & 293 \\
\hline Sm.odch. Muž & 173,0505 \\
\hline Sm.odch. Žena & 160,1194 \\
\hline
\end{tabular}

Tab. č. 1: Statistické vyhodnoceni průměrných hodnot času stráveného využiváním internetu podle pohlavi żáků (Studentův t-test). 


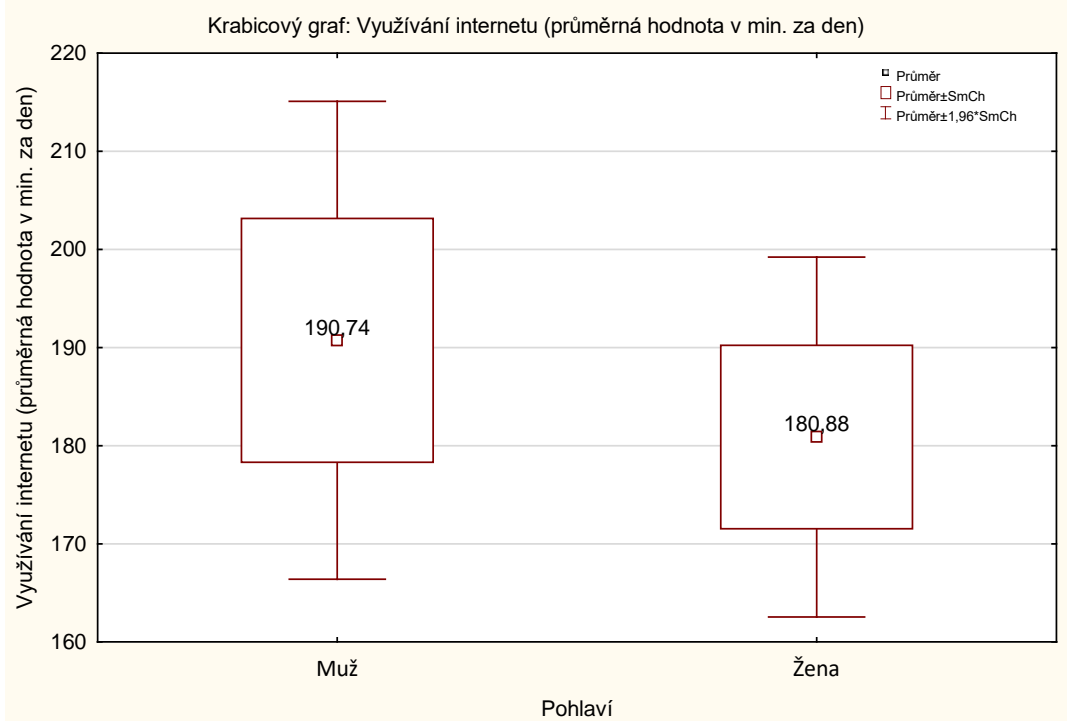

Graf č. 1: Průměrné hodnoty času stráveného využíváním internetu podle pohlavi žáků (Statistica 13, Studentùv t-test).

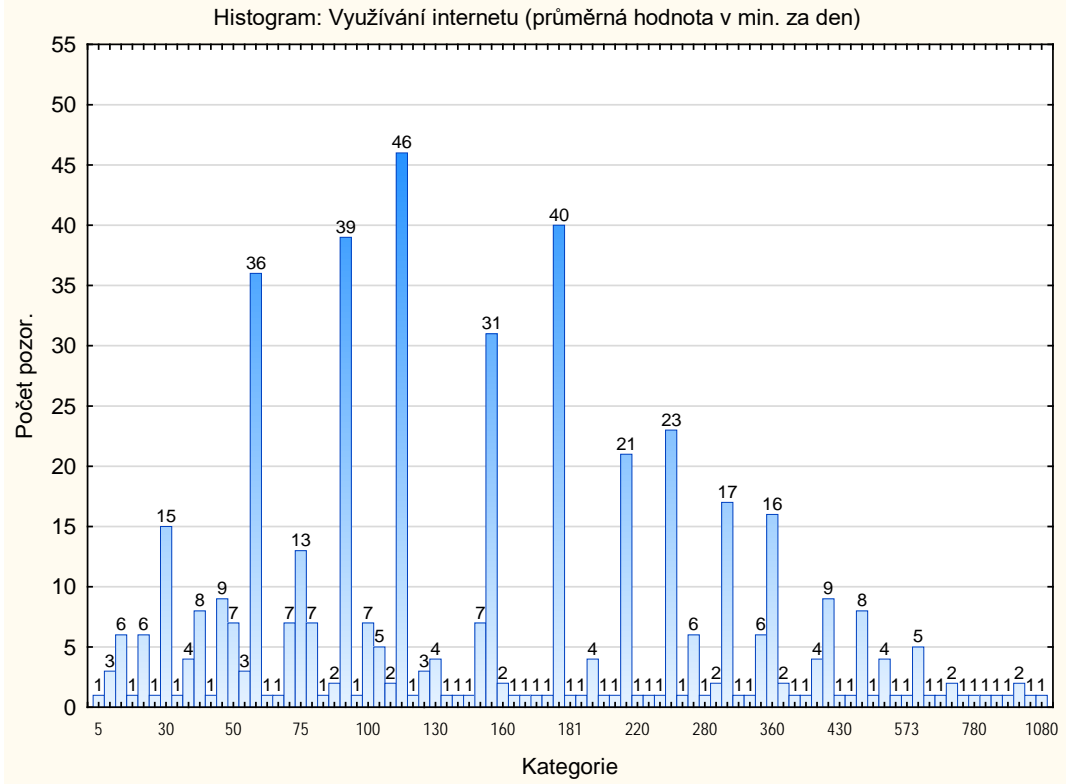

Graf č. 2: Histogram časových hodnot využivání internetu u gymnázií (Statistica 13). 
Vyhodnocení hypotézy bylo provedeno jen pro žáky, kteří uvedli průměrnou denní časovou hodnotu využívání internetu a uvedli své pohlaví v dotazníku. Hladina významnosti $\alpha$ byla zvolena 0,05 . Na základě vypočítané signifikance $p>0,05$ (viz tab. č. 1) nemůžeme odmítnout nulovou hypotézu $\mathrm{H}_{0}$ a príijmout hypotézu alternativní $\mathrm{H}_{\mathrm{A}}$ na zvolené hladině významnosti $5 \%$. Zjištěné rozdíly mezi pohlavím byly minimální.

Hypotéza $\mathbf{H}_{1}$ : Čas strávený využíváním internetu je u žáků 3. ročníků gymnázií delší u mužů než u žen, nebyla dokázána.

\section{$H_{2}$ : Čas strávený využíváním internetu pro školní potřeby je u žáků 3. ročníků gymnázií delší u žen než u mužů.}

Cílem hypotézy bylo zjistit, zda jsou rozdíly v času využíváni internetu pro školní potřeby u mužů a žen (2 kategorie: muži, ženy). Vycházeli jsme z faktu, že pokud ženy využívají internetu využívají je spíše pro vzdělávací účely, než je tomu u mužů. Hypotézu jsme dokazovali na základě odpovědí žáků na otázku „O: Kolik hodin a minut v prưměru za jeden den trávite využiváním internetu pro školní potřeby?“ a „O: Pohlaví“. Pro vyhodnocení hypotézy byla použita statistická metoda Studentův t-test (Chráska, 2016). Pro potřeby statistického vyhodnocení výzkumné hypotézy byla stanovena nulová a alternativní hypotéza $\mathrm{H}_{0}$ a $\mathrm{H}_{\mathrm{A}}$ :

Ho: Čas strávený využíváním internetu pro školní potřeby je u žáků 3. ročníků gymnázií stejný u žen a mužù.

$\mathbf{H}_{\mathrm{A}}$ : Čas strávený využíváním internetu pro školní potřeby je u žáků 3. ročníků gymnázií delší u žen než u mužů.

\begin{tabular}{|c|c|}
\hline \multicolumn{2}{|c|}{$\begin{array}{l}\text { t-testy; grupováno: Pohlaví (DATA výzkum) } \\
\text { Skup. 1: Muž } \\
\text { Skup. 2: Žena }\end{array}$} \\
\hline \multicolumn{2}{|c|}{ Proměnná } \\
\hline \multicolumn{2}{|c|}{$\begin{array}{l}\text { Využívání internetu pro školní potřeby (průměrná hodnota } \\
\qquad \text { min. za den) }\end{array}$} \\
\hline Průměr Muž & 53,72626 \\
\hline Průměr Žena & 64,84859 \\
\hline $\mathrm{t}$ & $-1,60045$ \\
\hline SV & 461 \\
\hline $\mathrm{p}$ & 0,110183 \\
\hline Poč. plat. Muž & 179 \\
\hline Poč. plat. Žena & 284 \\
\hline Sm.odch. Muž & 75,17282 \\
\hline Sm.odch. Žena & 71,29966 \\
\hline
\end{tabular}

Tab. č. 2: Statistické vyhodnoceni průměrných hodnot času stráveného využiváním internetu pro školni potřeby podle pohlavížákỉ (Studentův t-test). 


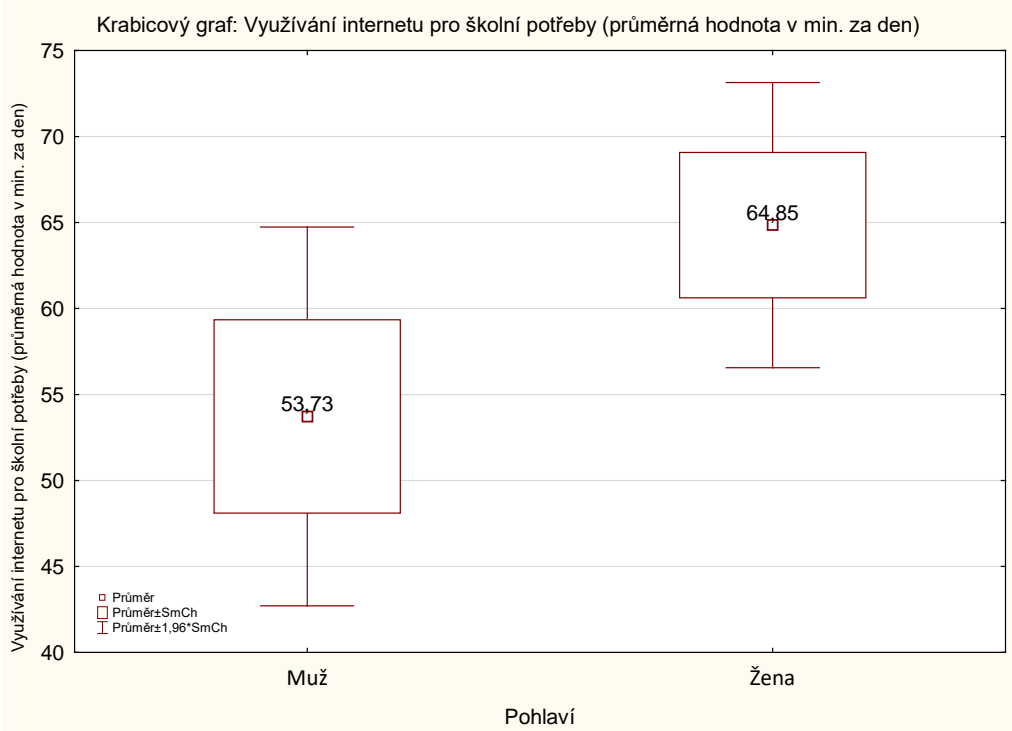

Graf č. 3: Průměrné hodnoty času stráveného využíváním internetu pro školní potřeby podle pohlaví žáků (Statistica 13, Studentův t-test).

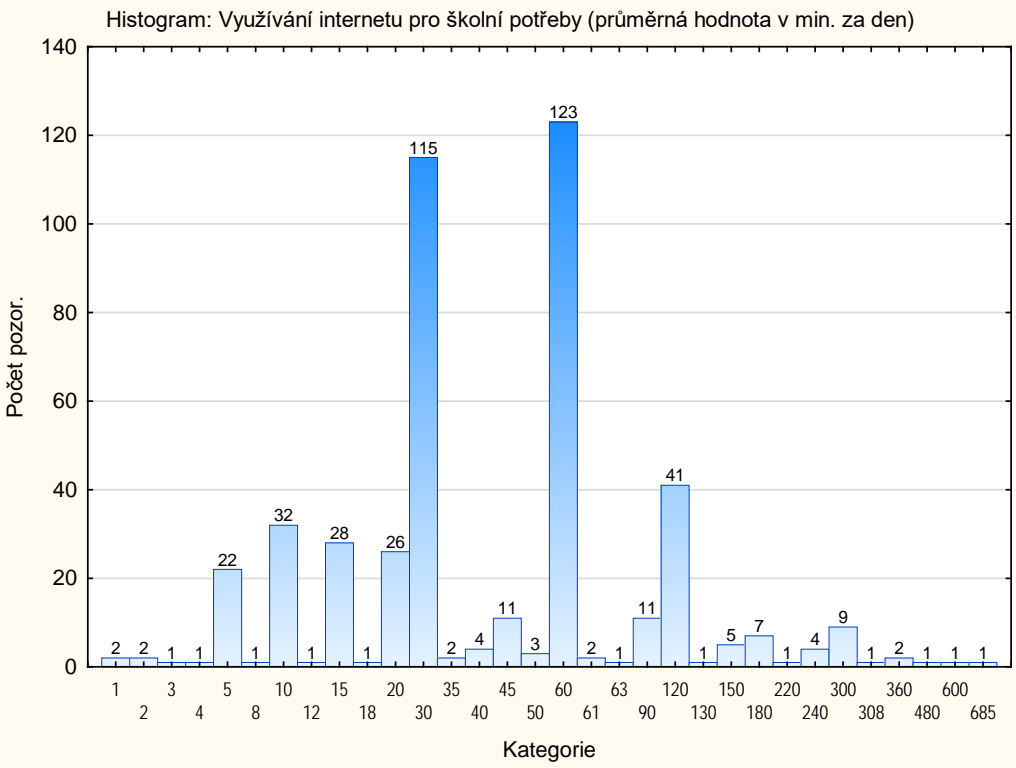

Graf č. 4: Histogram časových hodnot využivání internetu pro školní potřeby u gymnázií (Statistica 13). 
Vyhodnocení hypotézy bylo provedeno jen pro žáky, kteří uvedli průměrnou denní časovou hodnotu využívání internetu pro školní potřeby a uvedli své pohlaví v dotazníku. Hladina významnosti $\alpha$ byla zvolena 0,05 . Na základě vypočítané signifikance $p>0,05$ (viz tab. č. 2) nemůžeme odmítnout nulovou hypotézu $\mathrm{H}_{0}$ a přijmout hypotézu alternativní $\mathrm{H}_{\mathrm{A}}$ na zvolené hladině významnosti $5 \%$.

Hypotéza $\mathbf{H}_{2}$ : Čas strávený využiváním internetu pro školní potřeby je u žáků 3. ročníků gymnázií delší u žen než u mužů, nebyla dokázána.

I přes statistickou neprůkaznost však můžeme konstatovat, že ženy využívají ve větší míře internet pro školní potřeby než muži. Rozdíly ovšem nejsou statisticky významné.

\section{$H_{3}$ : Čas strávený hraním on-line počítačových her je u žáků 3. ročníků gymnázií delší u mužů než u žen.}

Cílem hypotézy bylo zjistit, zda jsou rozdíly v času využíváni sociálních sítí u mužů a žen (2 kategorie: muži, ženy). Vycházeli jsme z faktu, že muži hrají počítačové hry výrazně více než ženy (Basler, Mrázek, 2018). Hypotézu jsme dokazovali na základě odpovědí žáků na otázku „O: Kolik hodin a minut v průměru za jeden den hrajete on-line počitačové hry?“ a „O: Pohlaví“. Pro vyhodnocení hypotézy byla použita statistická metoda Studentův t-test (Chráska, 2016). Pro potřeby statistického vyhodnocení výzkumné hypotézy byla stanovena nulová a alternativní hypotéza $\mathrm{H}_{0}$ a $\mathrm{H}_{\mathrm{A}}$ :

$\mathbf{H}_{0}$ : Čas strávený hraním on-line počítačových her je u žáků 3. ročníků gymnázií stejný u mužů a žen.

$\mathbf{H}_{\mathrm{A}}$ : Čas strávený hraním on-line počítačových her je u žáků 3. ročníků gymnázií delší u mužů než u žen.

\begin{tabular}{|c|c|}
\hline \multicolumn{2}{|c|}{$\begin{array}{l}\text { t-testy; grupováno: Pohlaví (DATA výzkum) } \\
\text { Skup. 1: Muž } \\
\text { Skup. 2: Žena }\end{array}$} \\
\hline \multicolumn{2}{|c|}{ Proměnná } \\
\hline \multicolumn{2}{|c|}{$\begin{array}{c}\begin{array}{c}\text { Hraní on-line počítačových her (průměrná hodnota v min. za } \\
\text { den) }\end{array} \\
\end{array}$} \\
\hline Průměr Muž & 106,1623 \\
\hline Průměr Žena & 35,83562 \\
\hline $\mathrm{t}$ & 5,824209 \\
\hline sv & 225 \\
\hline $\mathrm{p}$ & 0,000000 \\
\hline Poč. plat. Muž & 154 \\
\hline Poč. plat. Žena & 73 \\
\hline Sm.odch. Muž & 92,36086 \\
\hline Sm.odch. Žena & 66,61519 \\
\hline
\end{tabular}

Tab. č. 3: Statistické vyhodnocení prümèrných hodnot času stráveného hraním on-line počitačových her podle pohlavi žáků (Studentův t-test). 


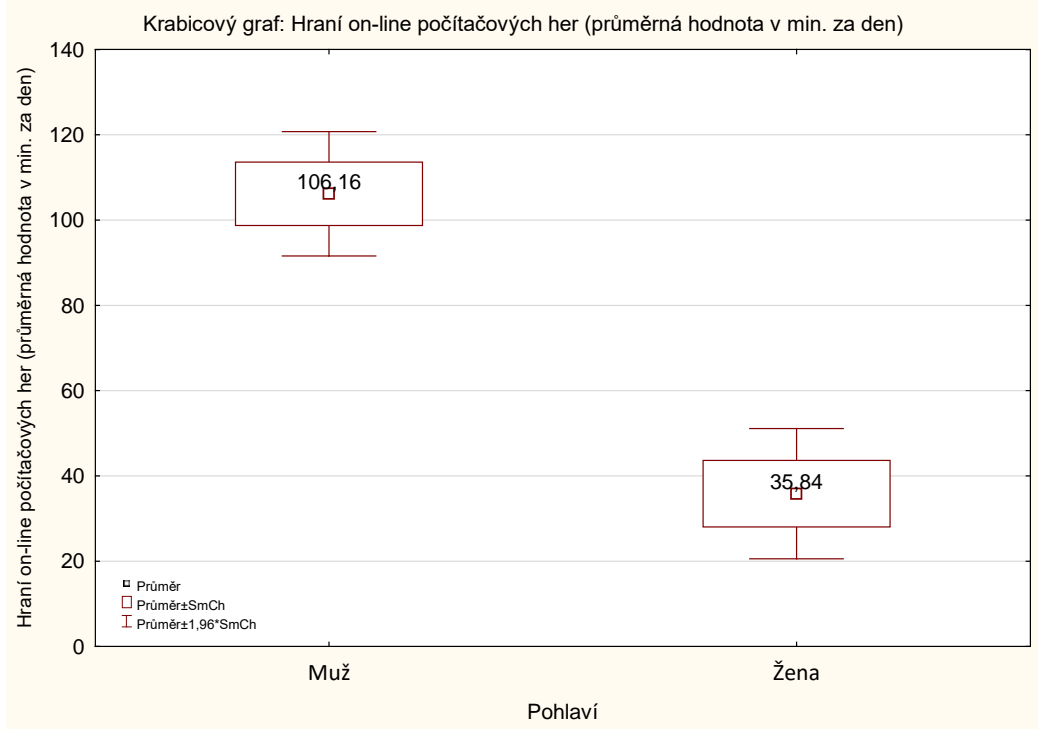

Graf č. 5: Prưměrné hodnoty času stráveného využíváním hraním on-line počítačových her podle pohlavížákủ (Statistica 13, Studentův t-test).

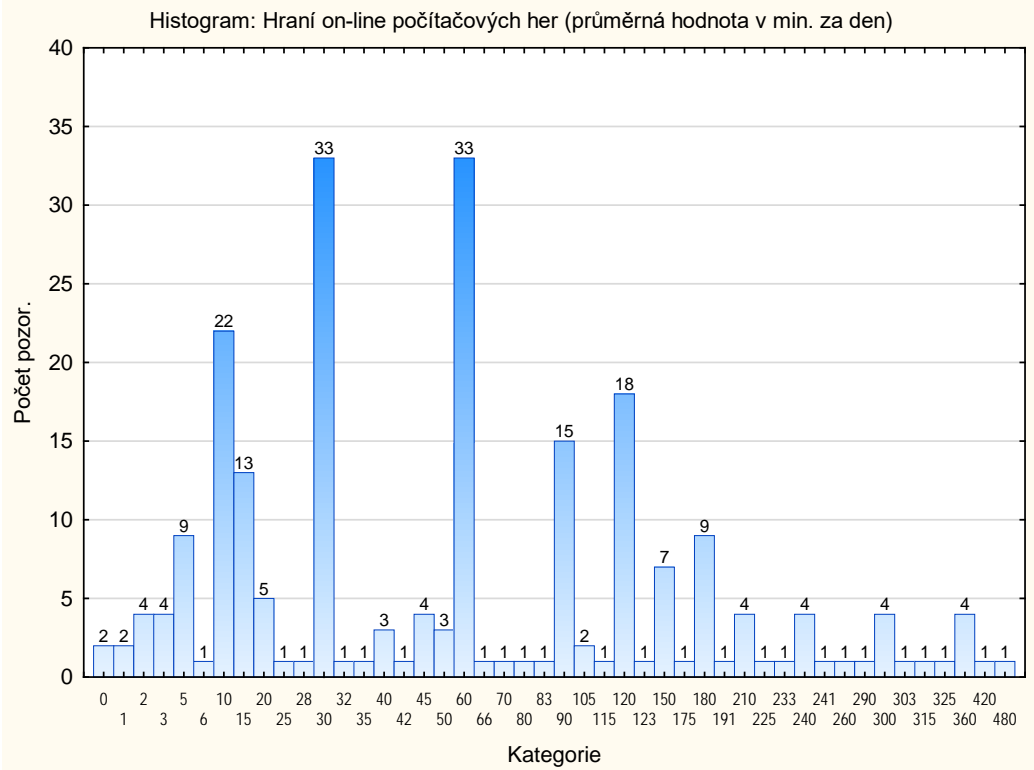

Graf č. 6: Histogram časových hodnot hrani on-line počitačových her u gymnázií (Statistica 13) - všechny kategorie. 


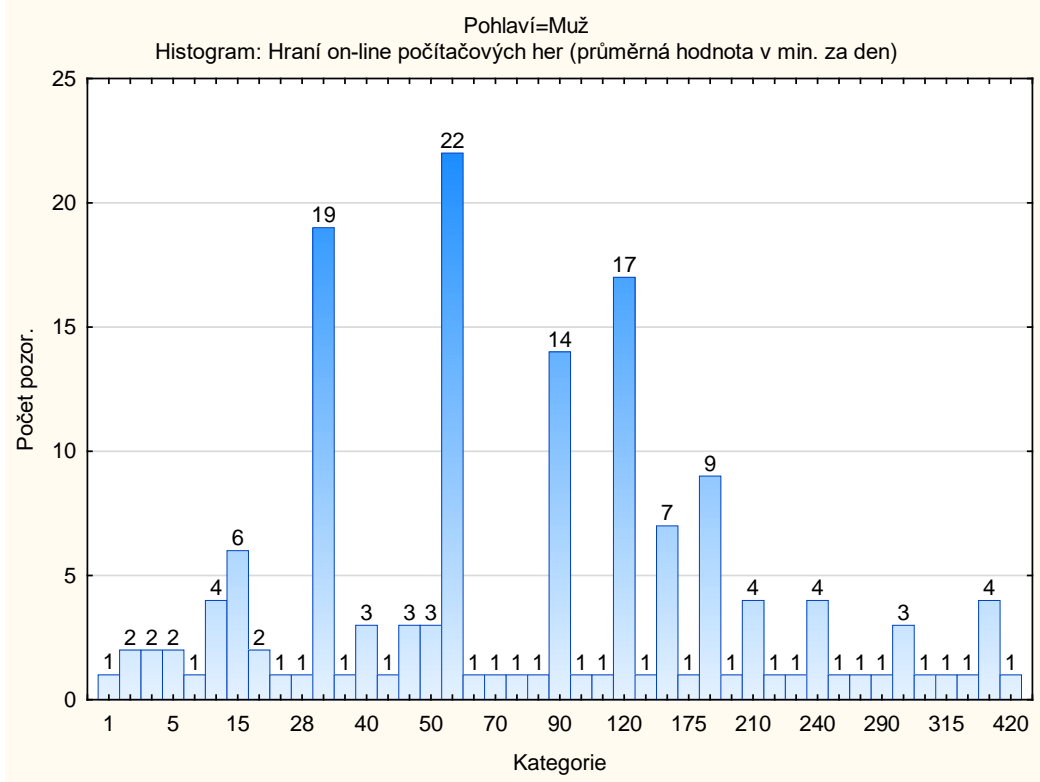

Graf č. 7: Histogram časových hodnot hraní on-line počítačových her u gymnázií (Statistica 13) - muži.

Pohlaví=Žena

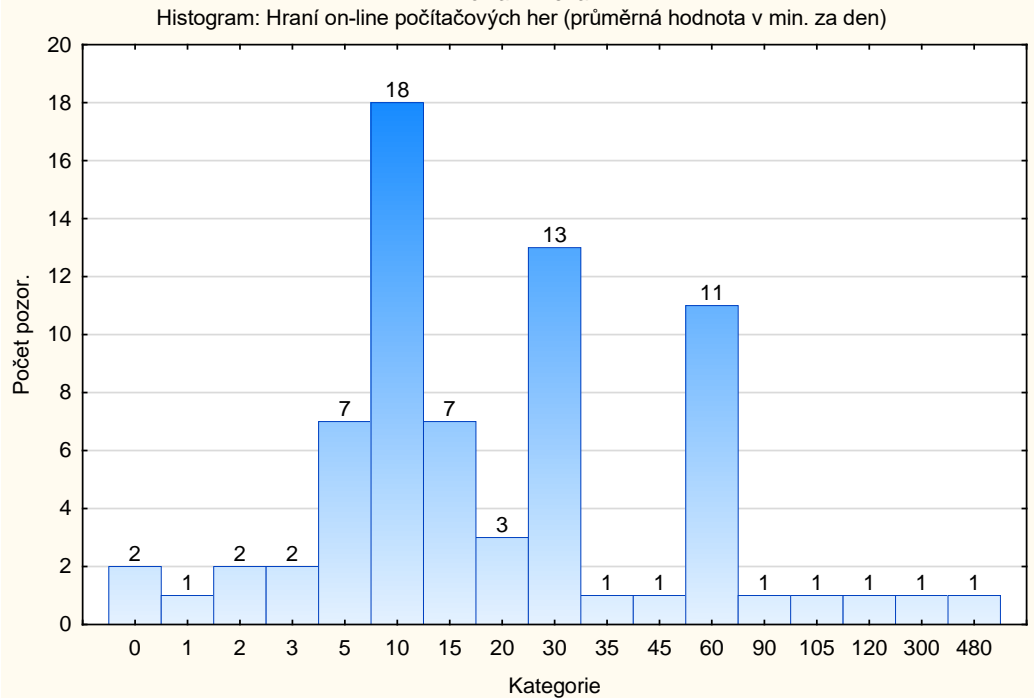

Graf č. 8: Histogram časových hodnot hraní on-line počitačových her u gymnázií (Statistica 13) - ženy. 
Vyhodnocení hypotézy bylo provedeno jen pro žáky, kteří uvedli průměrnou denní časovou hodnotu hraní on-line počítačových her a uvedli své pohlaví v dotazníku. Hladina významnosti $\alpha$ byla zvolena 0,05 . Na základě vypočítané signifikance $p<0,05$ (viz tab. č. 3) můžeme odmítnout nulovou hypotézu $\mathrm{H}_{0}$ a přijmout hypotézu alternativní $\mathrm{H}_{\mathrm{A}}$ na zvolené hladině významnosti $5 \%$.

Hypotéza $\mathbf{H}_{3}$ : Čas strávený hraním on-line počítačových her je u žáků 3. ročníků gymnázií delší u mužů než u žen., byla dokázána. Na základě zjištění můžeme konstatovat, že muži hrají on-line počítačové hry (průměrně 106,2 minut denně) ve významně větší míře než ženy (průměrně 35,8 minut denně).

\section{H4: Čas strávený využíváním sociálních sítí je u žáků 3. ročníků gymnázií delší u žen než u mužů.}

Cílem hypotézy bylo zjistit, zda jsou rozdíly v času využíváni sociálních sítí u mužů a žen (2 kategorie: muži, ženy). U této hypotézy jsme naopak vycházeli z předpokladu, že v př́padě, že ženy hrají málo on-line počítačové hry $\left(\mathrm{H}_{3}\right)$, ale využívají internet téměř ve stejné míře jako muži $\left(\mathrm{H}_{1}\right)$ pravděpodobně budou využívat ve vyšší míre právě sociální sítě. Hypotézu jsme dokazovali na základě odpovědí žáků na otázku „O: Kolik hodin a minut v průméru za jeden den trávíte na sociálních sítich?“ a „O: Pohlaví“. Pro vyhodnocení hypotézy byla použita statistická metoda Studentův t-test (Chráska, 2016). Pro potřeby statistického vyhodnocení výzkumné hypotézy byla stanovena nulová a alternativní hypotéza $\mathrm{H}_{0}$ a $\mathrm{H}_{\mathrm{A}}$ :

$\mathbf{H}_{0}$ : Čas strávený využíváním sociálních sítí je u žáků 3. ročníků gymnázií stejný u žen a mužů.

$\mathbf{H}_{\mathrm{A}}$ : Čas strávený využíváním sociálních sítí je u žáků 3. ročníků gymnázií delší u žen než u mužů.

\begin{tabular}{|c|c|}
\hline \multicolumn{2}{|c|}{$\begin{array}{l}\text { t-testy; grupováno: Pohlaví (DATA výzkum) } \\
\text { Skup. 1: Muž } \\
\text { Skup. 2: Žena }\end{array}$} \\
\hline \multicolumn{2}{|c|}{ Proměnná } \\
\hline \multicolumn{2}{|c|}{ Využívání sociálních sítí (průměrná hodnota v min. za den) } \\
\hline Průměr Muž & 113,5000 \\
\hline Průměr Žena & 179,8310 \\
\hline $\mathrm{t}$ & $-4,95264$ \\
\hline $\mathrm{sv}$ & 474 \\
\hline $\mathrm{p}$ & 0,000001 \\
\hline Poč. plat. Muž & 192 \\
\hline Poč. plat. Žena & 284 \\
\hline Sm.odch. Muž & 125,8544 \\
\hline Sm.odch. Žena & 154,0328 \\
\hline
\end{tabular}

Tab. č. 4: Statistické vyhodnoceni průměrných hodnot času stráveného využiváním sociálnich sití podle pohlavi žáků (Studentův t-test). 


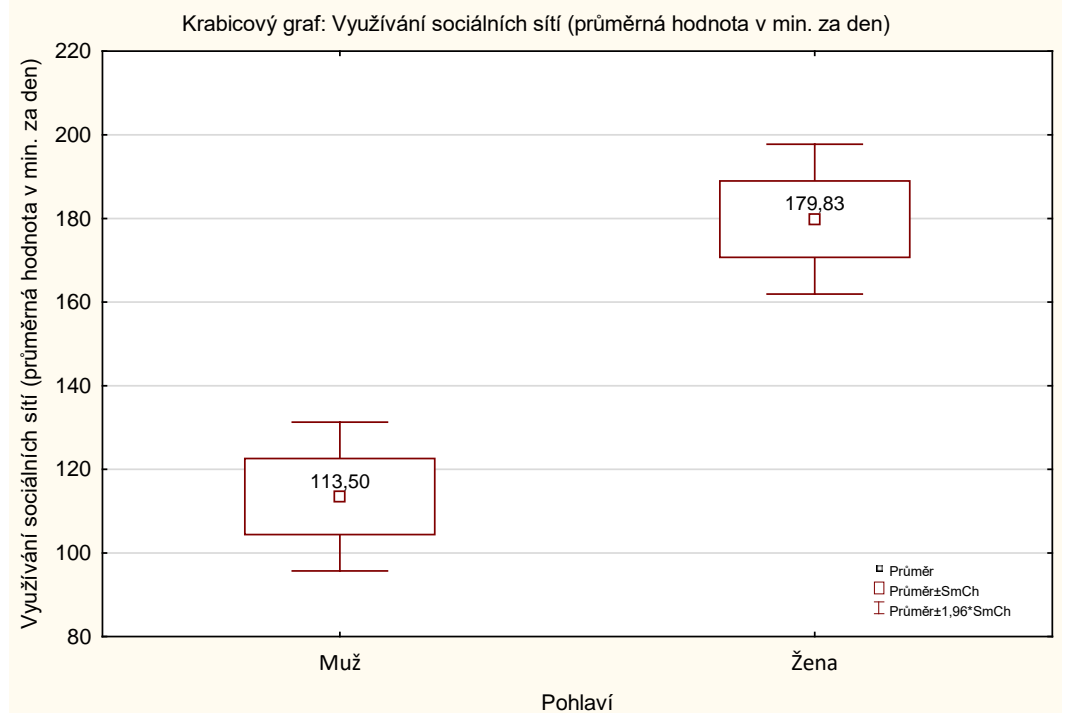

Graf č. 9: Průměrné hodnoty času stráveného využíváním sociálních sítí podle pohlaví žáki̊ (Statistica 13, Studentův t-test).

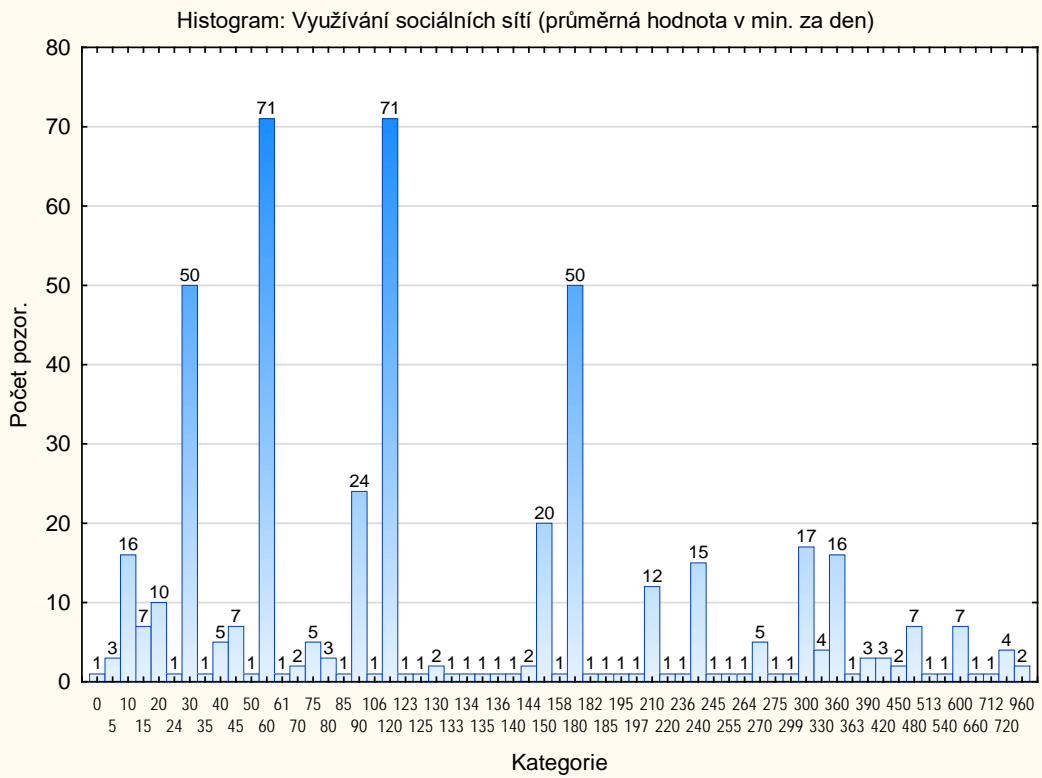

Graf č. 10: Histogram časových hodnot využiváni sociálních sítí u gymnázií (Statistica 13). 
Pohlaví=Muž

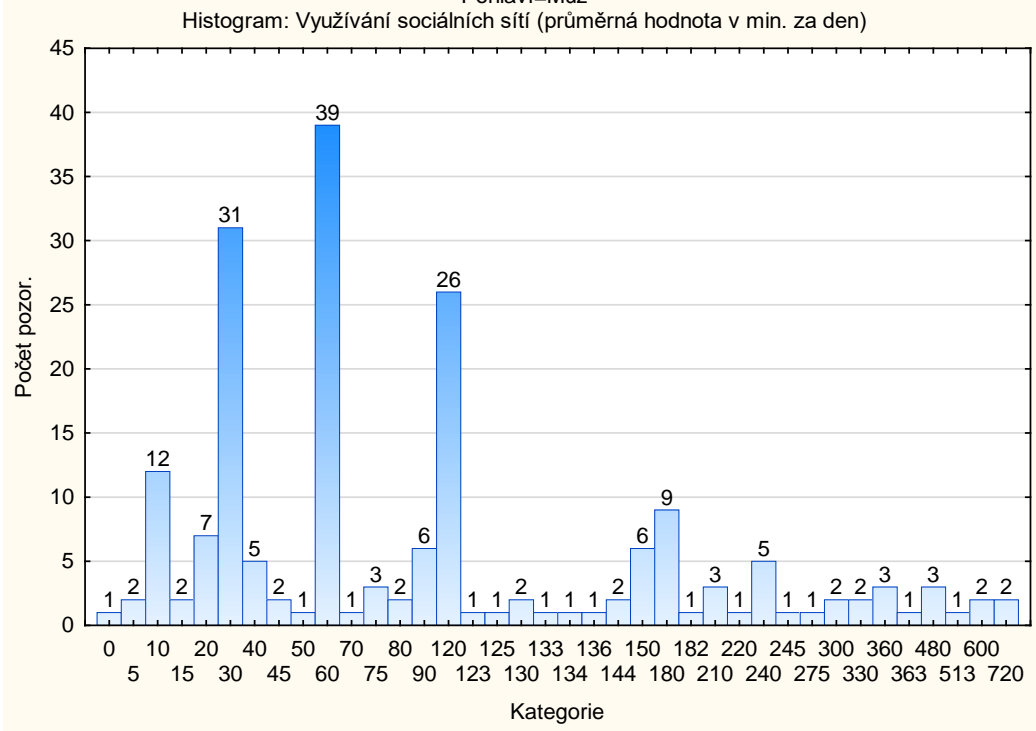

Graf č. 11: Histogram časových hodnot využiváni sociálních sití u gymnázií

(Statistica 13) - muži.

Pohlaví=Žena

Histogram: Využívání sociální sítí (průměrná hodnota v min. za den)

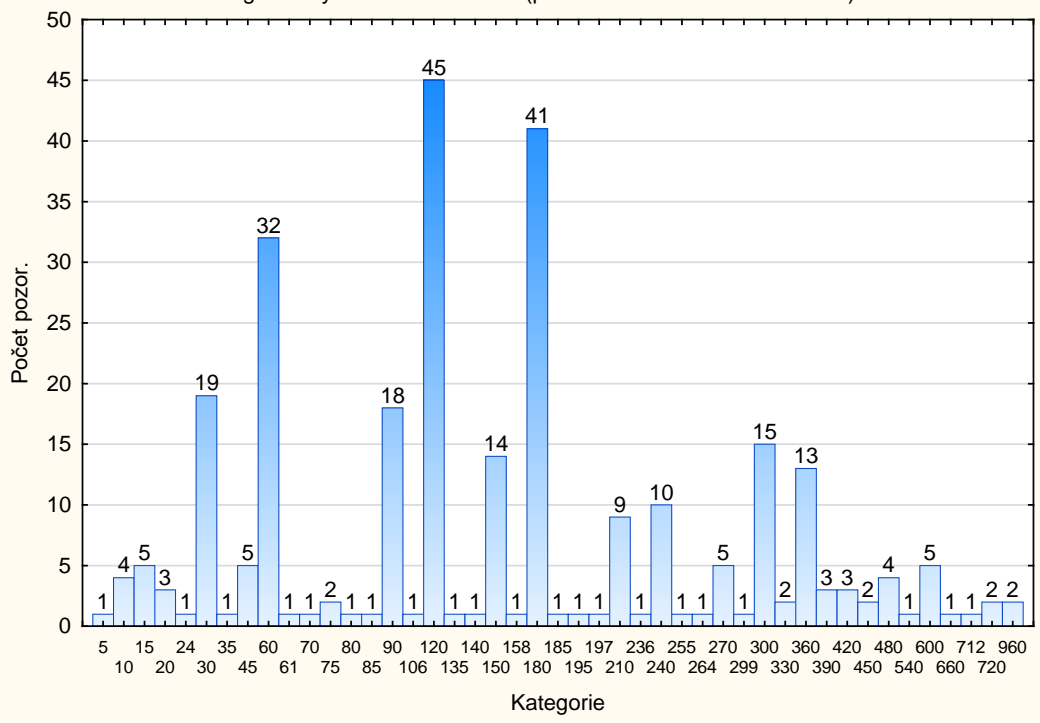

Graf č. 12: Histogram časových hodnot využívání sociálních sítí u gymnázií

(Statistica 13) - ženy. 
Vyhodnocení hypotézy bylo provedeno jen pro žáky, kteří uvedli průměrnou denní časovou hodnotu využívání sociálních sítí a uvedli své pohlaví v dotazníku. Hladina významnosti $\alpha$ byla zvolena 0,05 . Na základě vypočítané signifikance $p<0,05$ (viz tab. č. 4) můžeme odmítnout nulovou hypotézu $\mathrm{H}_{0}$ a přijmout hypotézu alternativní $\mathrm{H}_{\mathrm{A}}$ na zvolené hladině významnosti $5 \%$.

Hypotéza $\mathbf{H}_{4}$ : Čas strávený využíváním sociálních sítí je u žáků 3. ročníků gymnázií delší u žen než u mužů., byla dokázána.

Zde, se nám náš výchozí předpoklad potvrdil a ženy opravdu využívají sociální sítě statisticky významně více než muži.

\section{H5: Skóre závislosti na internetu je u žáků 3. ročníků gymnázií vy̌̌ší u mužů než u žen.}

Cílem hypotézy bylo zjistit, zda je skóre závislosti na internetu rozdílné u mužů a žen našeho výzkumného vzorku. Vycházeli jsme z faktu, že u našeho výzkumného vzorku byla statisticky dokázáno vyšší skóre závislosti na počítačových hrách než u žen (Basler, Mrázek, 2018), očekávali jsme zde totožné tendence. Hypotézu jsme dokazovali na základě vypočteného souhrnného skóre závislosti na internetu.

Analýza závislosti na internetu u žáků našeho výzkumného vzorku vychází z 26 škálových otázek obsažených v standardizovaném dotazníku, které zkoumají jednotlivé rysy závislosti na internetu (Chen et al., 2003):

- $\quad \mathrm{O}_{1}$ : Bylo mi víckrát než jednou řečeno, že na internetu trávím př́liš mnoho času.

- $\mathrm{O}_{2}$ : Po surfování na internetu mě bolívá v zádech, prípadně pocituji jiné fyzické potiže.

- $\mathrm{O}_{3}$ : Zjišstuji, že se vyžívám na internetu na úkor toho, abych se stýkal(a) se svými kamarády.

- $\quad \mathrm{O}_{4}$ : Myšlenka na to, že se prípojím na internet, je první věc, která mě každý den ráno hned po probuzení napadne.

- $\quad \mathrm{O}_{5}$ : Nedaří se mi zvládat své nutkání připojit se na internet.

- $\mathrm{O}_{6}$ : Více než jednou se mi stalo, že jsem kvůli internetu spal/a méně než čtyři hodiny.

- $\quad \mathrm{O}_{7}$ : Surfování na internetu se negativně projevuje na mém tělesném zdraví.

- $\mathrm{O}_{8}$ : Přestože se uživání internetu negativně odrazilo na mých vztazích $\mathrm{s}$ jinými lidmi, množství času, které na internetu trávím, se nezmenšilo.

- $\quad O_{9}:$ Když jsem nějakou dobu bez internetu, mám pocit, že mi něco chybí.

- $\mathrm{O}_{10}$ : Kvũli internetu trávím méně času s rodinou.

- $\mathrm{O}_{11}$ : Mé odpočinkové aktivity se omezují na užívání internetu.

- $\quad \mathrm{O}_{12}$ : Cítím se deprimovaný/á a skleslýlá, když na nějakou dobu přestanu internet užívat.

- $\mathrm{O}_{13}$ : Doba, kterou týdně trávím na internetu, se za poslední pololetí (resp. za posledních 6 měsíců) výrazně zvýšila.

- $\mathrm{O}_{14}$ : Trávení času na internetu má určitý negativní dopad na mé výsledky ve škole/můj pracovní výkon.

- $\mathrm{O}_{15}$ : Nedaří se mi zvládat své nutkání príipojit se na internet poté, co jsem se již odhlásil/a, abych mohl/a dělat nějakou jinou plánovanou práci.

- $\mathrm{O}_{16}$ : Kdyby nebylo internetu, neměl/a bych $\mathrm{v}$ životě mnoho radosti.

- $\quad \mathrm{O}_{17}$ : Snažím se trávit na internetu méně času, ale mé snahy jsou marné.

- $\quad \mathrm{O}_{18}$ : Zůstávám online po delší dobu, než jsem měl/a v úmyslu, i když jsem měl/a původně v plánu jen se na něco rychle podívat.

- $\mathrm{O}_{19}$ : Jakmile se dostanu na internet, vjede do mě nová energie bez ohledu na únavu, kterou cítím. 
- $\quad \mathrm{O}_{20}$ : Během dne se cítím unavený/á, protože dlouho do noci surfuji na internetu.

- $\mathrm{O}_{21}$ : Kvůli užívání internetu nepravidelně jím.

- $\quad \mathrm{O}_{22}$ : Musím na internetu trávit stále více času, abych dosáhl/a stejného uspokojení jako předtím.

- $\quad \mathrm{O}_{23}$ : Zvykám si méně spát, abych mohl/a trávit více času na internetu.

- $\quad \mathrm{O}_{24}$ : Jsem neklidný/á a podrážděný/á, když připojení na internet nefunguje nebo když není takové připojení $\mathrm{k}$ dispozici.

- $\mathrm{O}_{25}:$ Zjišt'uji, že trávím na internetu stále více času.

- $\quad \mathrm{O}_{26}$ : Když po určitou dobu nechodím na internet, začnu se cítit nesvůj/nesvá.

Jednotlivým škálovým možnostem otázek jsme udělili váhu od 0 do 3 (nikdy - téměr nikdy - často - téměr vždy). Na základě těchto odpovědí bylo počítáno souhrnné skóre závislosti na internetu. Maximální hodnota skóre závislosti na internetu činila 78 bodů. Bylo stanoveno, že pokud respondent dosahuje skóre závislosti na internetu 40 a více, vykazuje nadprůměrné znaky závislostního chování a je tedy závislý na internetu (Basler, Mrázek, 2019).

Výpočet skóre závislosti na internetu byl prováděn pouze pro respondenty, kteří odpověděli na všechny zmiňované předchozí otázky a uvedli v dotazníku své pohlaví. $\mathrm{Z}$ tohoto důvodu byly následující analýzy provedeny pro 491 respondentů (muži=193, ženy=298) z celkových 529.

Pro vyhodnocení hypotézy byla použita statistická metoda Studentův t-test. Pro potřeby statistického vyhodnocení výzkumné hypotézy byla stanovena nulová a alternativní hypotéza $\mathrm{H}_{0}$ a $\mathrm{H}_{\mathrm{A}}$ :

Ho: Skóre závislosti na internetu je u žáků 3. ročníků gymnázií stejné u mužů a žen. $\mathrm{H}_{\mathrm{A}}$ : Skóre závislosti na internetu je u žáků 3. ročníků gymnázií vyšší u mužů než u žen.

\begin{tabular}{|c|c|}
\hline $\begin{array}{l}\text { t-testy; grupováno: Pohlaví (DATA výzkum) } \\
\text { Skup. 1: Muž } \\
\text { Skup. 2: Žena }\end{array}$ \\
\hline \multicolumn{2}{|c|}{ Proměnná } \\
\hline \multicolumn{2}{|c|}{ Skóre závislosti na internetu } \\
\hline Průměr Muž & 16,38860 \\
\hline Průměr Žena & 17,89262 \\
\hline t & $-1,53197$ \\
\hline sv & 489 \\
\hline p & 0,126176 \\
\hline Poč. plat. Muž & 193 \\
\hline Poč. plat. Žena & 298 \\
\hline Sm.odch. Muž & 10,60264 \\
\hline Sm.odch. Žena & 10,64021 \\
\hline
\end{tabular}

Tab. č. 5: Statistické výsledky průměrných hodnot skóre závislosti na internetu u mužů a žen gymnázií (Studentův t-test) (Basler, Mrázek, 2019). 


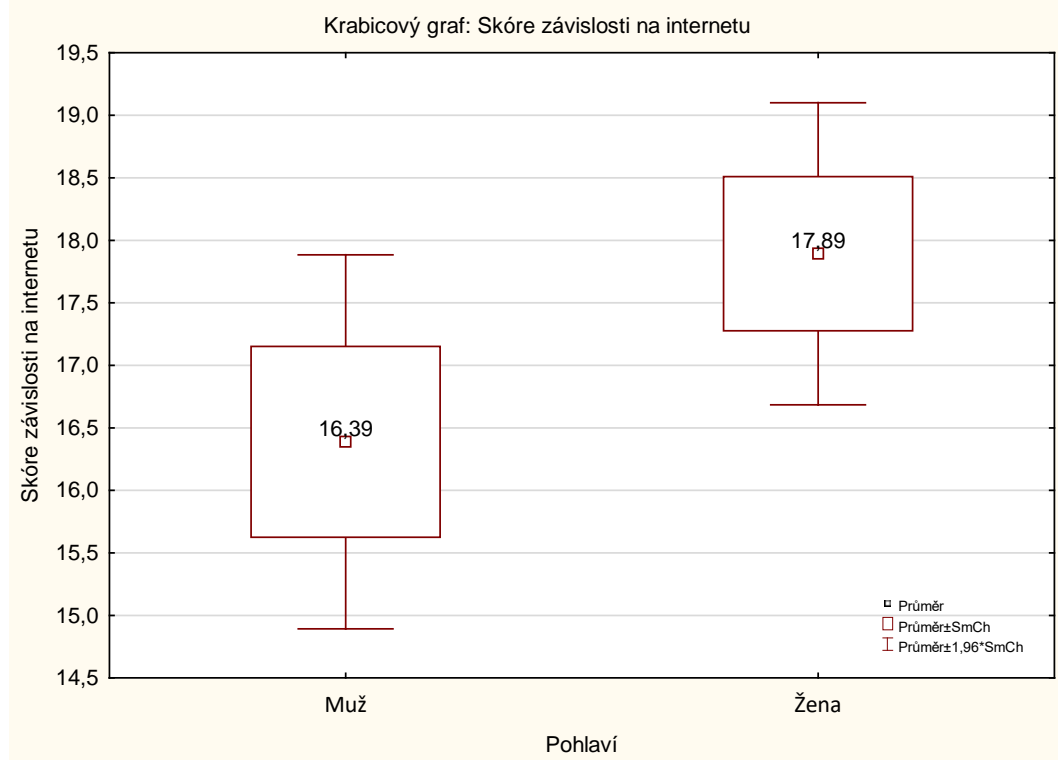

Graf č. 13: Krabicový graf prüměrných hodnot skóre závislosti na internetu u mužů a žen (Statistica 13, Studentův t-test) (Basler, Mrázek, 2019).

Pro potřeby vyhodnocení hypotézy bylo pro každého žáka vypočitáno skóre na základě jeho odpovědí (maximální skóre činilo 78 bodů). Hladina významnosti $\alpha$ byla zvolena 0,05 . Na základě vypočitané signifikance $\mathrm{p}>0,05$ nemůžeme na hladině významnosti $5 \%$ odmítnout nulovou hypotézu $\mathrm{H}_{0}$ a príijmout hypotézu alternativní $\mathrm{H}_{\mathrm{A}}$.

Mírné rozdíly mezi pohlavími v distribuci skóre závislosti na internetu se vyskytovaly, ovšem nejednalo se o statisticky významné rozdíly, hypotéza $\mathbf{H}_{5}$ tedy nebyla dokázána. 


\section{Diskuse a závěr}

Na základě výsledků našeho výzkumného šetření můžeme konstatovat, že v rámci vyhodnocení dat byly potvrzeny hypotézy $\mathrm{H}_{3}-\mathrm{H}_{4}$ (z celkového počtu 5 hypotéz) a byly potvrzeny genderové rozdíly ve využívání on-line počítačových her a sociálních sítí mezi muži a ženami.

V roce 2016 vyšla podobně zaměřená výzkumné studie autorského kolektivu Dufour et al., která se zaměřovala na genderové rozdíly v užívání internetu a s ním spojená rizika, včetně závislosti na internetu, u kanadských adolescentů na středních školách ve státě Quebec. S ohledem na naše výzkumná zjištění lze vybrané výsledky s touto studií komparovat, především v kontextu mezinárodních rozdílů.

Při vyhodnocení hypotézy $\mathrm{H}_{1}$ bylo zjištěno, že časová míra využívání internetu je téměř totožná u mužů (průměr 190,7 minut denně) i žen (průměr 180,9 minut denně). Porovnáním výsledků se zmíněnou studií zjistíme, že středoškoláci v České republice tráví na internetu více času, přibližně o 3 hodiny více za týden, přičemž ve světě se týdenní průměrná doba užívání internetu pohybuje v rozmezí 8-15 hodin (Dufour et al., 2016). Zároveň v našem výzkumu nebyl prokázán genderový rozdíl ve využívání internetu, který se u kanadských adolescentů prokázal. Skutečnost může ovlivňovat především rozdílnost socio-kulturních podmínek, ale i vývoj užívání internetu, kdy se genderové rozdíly mohou vyrovnávat.

Dále jsme zkoumali dílčí využívání internetu pouze pro školní potřeby, domnívali jsme se, že ženy budou využívat více internet pro školní potřeby než muži. Vycházeli jsme z předpokladu, že ženy totožného výzkumného vzorku hrají v mnohem větší míře výukové (též didaktické) počítačové hry než muži (Basler, Mrázek, 2018). Tuto tezi jsme ovšem statisticky nedokázali $\left(\mathrm{H}_{2}\right)$. I přes statistickou neprůkaznost však můžeme konstatovat, že ženy využívají ve větší míře internet pro školní potřeby než muži (průměr ženy - 64,9 minut denně; průměr muži - 53,7 minut denně). Rozdíly ovšem nejsou statisticky významné. Avšak jsou i výzkumné studie např. Thanuskodi (2013), kde je tendence přesně opačná a muži využívají pro edukační účely internet více než ženy.

$\mathrm{Na}$ základě vyhodnocení hypotézy $\mathrm{H}_{3}$ bylo zjištěno, že čas strávený hraním on-line počítačových her je u žáků 3. ročníků gymnázií delší u mužů než u žen. Muži hráli on-line počítačové hry průměrně 106,2 minut denně a ženy pouze 35,8 minut denně. Zde jsme zjistili vysoce významný statistický rozdíl a tento výsledek nám potvrzuje výrazné genderové rozdíly mezi muži a ženami. Dále jsme zkoumali využívání sociálních sítí u našeho výzkumného vzorku a vycházeli jsme z předpokladu, že v př́padě, že ženy hrají málo on-line počítačové hry $\left(\mathrm{H}_{3}\right)$, ale využívají internet téměř ve stejné míre jako muži $\left(\mathrm{H}_{1}\right)$ pravděpodobně budou využívat ve vyšší míře právě sociální sítě.

V rámci vyhodnocení hypotézy $\mathrm{H}_{4}$ jsme dokázali, že čas strávený využíváním sociálních sítí je u žáků 3. ročníků gymnázií delší u žen než u mužůa a to statisticky významně (průměr ženy - 179,8 minut denně; průměr muži - 113,5 minut denně). Náš předpoklad byl tedy správný. Naše výsledky hypotéz $\mathrm{H}_{3}$ a $\mathrm{H}_{4}$ korespondují s výzkumným šetřením Dufour et al. (2016), ve kterém byla dále realizována komparace ve shodě s evropskými studiemi. Genderové trendy užívání internetu jsou ve světovém měřítku velmi podobné. Hraní on-line počítačových her je především doménou mužů, naopak ženy dominují ve využívání sociálních sítí.

V rámci poslední hypotézy $\mathrm{H}_{5}$ jsme se zaměřili na genderové rozdíly ve skóre závislosti na internetu. Poslední hypotéza ovšem nebyla potvrzena, nebyly zjištěny statisticky významné rozdíly ve skóre závislosti na internetu mezi muži a ženami. Dokonce 
bylo zjištěno mírně vyšší průměrné skóre závislosti na internetu u žen (17,9 bodů) než u mužů ( 16,4 bodů). Na totožném výzkumném vzorku probíhal taktéž výzkum zaměřen na závislost na počítačových hrách (uplatněna podobná výzkumná metodika, jenž se zakládala na závislostních kritériích zaměřené na hraní počítačových her) a bylo zjištěno, že skóre závislosti na počítačových hrách je statisticky významně vyšší u mužů než u žen a byly potvrzeny významné rozdíly $\mathrm{v}$ podílu závislých na počítačových hrách mezi muži a ženami (Basler, Mrázek, 2018), proto jsme předpokládali totožné tendence u závislosti na internetu, ovšem náš výchozí předpoklad nebyl potvrzen. Výsledek hypotézy $\mathrm{H}_{5}$ není v souladu se zahraniční výzkumnou studií Bakken et al. (2009), která udává, že se u mužů vyskytuje závislostní chování více než u žen. Současně je ale nutné poukázat na výsledek výzkumné studie Dufour et al. (2016), který naopak koresponduje s naším zjištěním. I zde nebyly zjištěny statisticky významné genderové rozdíly ve skóre závislosti na internetu a současně se zde také projevilo mírně vyšší průměrné skóre závislosti na internetu u žen.

Z hlediska dostupných studií a zdrojů zle vypozorovat, že genderové rozdíly užívání internetu mezi českými adolescenty, výhradně pak u zkoumaného vzorku, se významně neliší od mezinárodních trendů. V obecné rovině průměrné doby uživání internetu lze ovšem konstatovat, že žáci vybraných gymnázií v České republice patří ve světovém měřitku do skupiny časově nadprůměrných uživatelů internetu. Je ovšem nutné vzít v úvahu, do jaké míry by byly výsledky totožné, pokud bychom analýzu prováděli u studentů různých středních škol.

Př́spěvek vznikl za podpory projektu IGA_PdF_2019_043 s názvem Analýza vybraných aktuálních problémů ve výuce informaticky zaměřených předmětů s akcentem na on-line technologie.

\section{Literatura}

Bakken, I.J., Wenzel, H.G., Götestam, K.G., Johansson, A. \& Øren, A. (2009). Internet addiction among Norwegian adults: A stratified probability sample study. Scandinavian Journal of Psychology; 50(2): 121-127. DOI: 10.1111/j.1467-9450.2008.00685.x.

Basler, J. \& Mrázek, M. (2019). Internet Addiction among grammar school students in the Czech Republic. In ICERI2019 Proceedings, Seville, Spain: IATED. In print.

Basler, J., \& Mrázek, M. (2018). Počitačové hry a jejich misto v životě člověka. Olomouc: Univerzita Palackého v Olomouci. DOI: 10.5507/pdf.18.24454047.

Český statistický úr̆ad. (2017). Využivání informačnich a komunikačnich technologií $v$ domácnostech a mezi jednotlivci. Praha: ČŠI.

Dufour, M., Brunelle, N., Tremblay, J., Leclerc, D., Cousineau, M.M., Khazaal, Y., Légaré, A.A., Rousseau, M. \& Berbiche, D. (2016). Gender Difference in Internet Use and Internet Problems among Quebec High School Students. The Canadian Journal of Psychiatry. 61(10). 663-668. DOI: 10.1177/0706743716640755.

ESA. (2017). Essential facts about the computer and video game industry. Washington: ESA.

Dostupné z: http://www.theesa.com/wpcontent/uploads/2017/09/EF2017_Design_FinalDigital.pdf

Green, M. E. \& McNeese, M. N. (2008). Factors that predict digital game play. Howard Journal of Communications, 19(3). 258-272. DOI: 10.1080/10646170802218321. 
Hellstrom, C., Nilsson, K. W., Leppert, J., \& Áslund, C. (2015). Effects of adolescent online gaming time and motives on depressive, musculoskeletal, and psychosomatic symptoms. Upsala Journal of Medical Sciences, 120(4). 263-75. DOI: 10.3109/03009734. Chen, S.-H., Weng, L.-J., Su, Y.-J., Wu, H.-M., \& Yang, P.-F. (2003). Development of a Chinese Internet Addiction Scale and Its Psychometric Study. Chinese Journal of Psychology, 45(3), 279-294. DOI: 10.1037/t44491-000.

Chráska, M. (2016). Metody pedagogického výzkumu: základy kvantitativního výzkumu, Praha: Grada Publishing.

Klinika adiktologie. (2010). Jak závislost na internetu vypadá? Závislost na internetu [cit. 2019-11-04]. Dostupné z: http://poradna.adiktologie.cz/article/zavislost-na-internetu/jakzavislost-na-internetu-vypada/

Ko, C. H., Yen, J. Y., Yen, C. F., Chen, C. C., Yen, C. N., \& Chen, S. H. (2005). Screening for internet addiction: an empirical study on cut-off points for the Chen Internet Addiction Scale. Kaohsiung J Med Sci, 21(12), 545-551. DOI: 10.1016/S1607-551X(09)70206-2.

Kopecký, K., Szotkowski R. \& Krejčí V. (2015) Rizikové formy chování českých a slovenských dětí v prostředí internetu. Univerzita Palackého v Olomouci. DOI: 10.5507/pdf.15.24448619.

Lenhart, A., Dean, J. K., Middaugh, E., Macgill, A. R., Evans, C., \& Vitak, J. (2008). Teens, video games and civics, teens' gaming experiences are diverse and include social interaction and civic engagement. Pew Research Center: Internet \& Technology. Dostupné z: http://www.pewinternet.org/2008/09/16/teens-video-games-and-civics/.

Longstreet, P., Brooks, S. \& Gonzales S. E. (2019). Internet addiction: When the positive emotions are not so positive. Technology in Society, 57. 76-85. DOI: 10.1016/j.techsoc.2018.12.004.

Messias, E., Castro, J., Saini, A., Usman, M., \& Peeples, D. (2011). Sadness, suicide, and their association with video game and internet overuse among teens: Results from the youth risk behavior survey 2007 and 2009. Suicide and Life-Threatening Behavior, 41(3). 307-315. DOI: 10.1111/j.1943-278X.2011.00030.x.

Müller, K. W. \& et al. (2014). Regular gaming behavior and internet gaming disorder in European adolescents: Results from a cross-national representative survey of prevalence, predictors, and psychopathological correlates. European Child and Adolescent Psychiatry, 24(5). 565-574. DOI: 10.1007/s00787-014-0611-2.

Ndasauka, Y., Pitafi, A. \& Kayange M. G. (2019). Psychometric properties of Young's Internet Addiction Test (IAT) in Urdu language. Asian Journal of Psychiatry, 40. 39-44. DOI: 10.1016/j.ajp.2019.01.011.

Pavlovská A. (2012). Chenova škála závislosti na internetu (Chen Internet Addiction Scale, CIAS). Klinika adiktologie. [cit. 2019-11-04]. Dostupné z: http://www.adiktologie.cz/cz/articles/detail/586/3612/Chenova-skala-zavislosti-nainternetu-Chen-Internet-Addiction-Scale-CIAS-

Peeters, M. M., Koning, I. \& Eijnden, R. (2018). Predicting Internet Gaming Disorder symptoms in young adolescents: A one-year follow-up study. Computers in Human Behavior, 80. 255-261. DOI: 10.1016/j.chb.2017.11.008. 
Sinkkonen, H.M., Puhakka, H. \& Meriläinen. (2014). Internet use and addiction among Finnish Adolescents (15-19 years). Journal of Adolescence, 37(2). 123-131. DOI: 10.1016/j.adolescence.2013.11.008.

Suchá, J., Dolejš, M. \& Pipová, H. (2019). Hraní digitálních her u českých adolescentů. Zaostřeno, 5 (4), 1-16.

Suchá, J., Dolejš, M., Pipová, H., Maierová, E., \& Cakirpaloglu, P. (2018). Hraní digitálních her českými adolescenty. Olomouc: Univerzita Palackého v Olomouci. DOI: 10.5507/ff.18.24454245.

Tahiroglu, A. Y., Celik, G. G., Uzel, M., Ozcan, N. \& Avci, A. (2008). Internet use among Turkish adolescents. CyberPsychology \& Behavior, 11(5). 537-543. DOI: 10.1089/cpb.2007.0165.

Thanuskodi, S. (2013). Gender Differences in Internet Usage among College Students: A Comparative Study. Library Philosophy and Practice (e-journal). Dostupné z: https://digitalcommons.unl.edu/libphilprac/1052/

Tonini, F., D’Alessandris, L., Lai, C., Martinelli, D., Corvino, S., Vasale, M. \& et al. (2012). Internet addiction: hours spent online, behaviours and psychological symptoms. General Hospital Psychiatry, 34. 80-87. DOI: 10.1016/j.genhosppsych.2011.09.013.

Vacek, J. (2010). Nelátkové závislosti: Behaviorální chování. Klinika adiktologie. [cit. 2019-11-04]. Dostupné z: http://www.adiktologie.cz/cz/articles/download/3476/Behavioralni-zavislosti-pdf Weinstein, A. \& Lejoyeux, M. (2010). Internet addiction or excessive Internet use. The American Journal of Drug and Alcohol Abuse, 36. 277-283. DOI: 10.3109/00952990.2010.491880. 